\title{
Exhibition of Technical and Scientific Chemical Apparatus at Cologne
}

\begin{abstract}
THE Seventh Achema (Exhibition of Technical and Scientific Chemical Apparatus) was duly held at Cologne in the spacious and centrally situated permanent exhibition buildings on May 18-27. It is a testimony both to the importance of the exhibition itself and to the newer national development of the chemical industry in all countries that it was very largely visited by foreigners. More than 2,000 were expected, including a considerable and influential party of British chemical and chemical-plant manufacturers, who spent several days in studying it and who are reported individually to have found the time well spent.
\end{abstract}

With past traditions to encourage her, Germany is striving to retain the lead which she formerly gained in this field, and although there was nothing particularly outstanding or novel on display, there was much among the exhibits of the three hundred firms to interest the serious. The method of display of the exhibits on small open stands of uniform character has much to commend it, and was thought by many to be preferable to the closed stands adopted at the British Industries Fair. Needless to say, the representatives at the stands were well versed in the technicalities of their wares and able usually to deal with technical points raised by the visitor, who frequently also found a willingness to discuss the special problems he brought forward at further private meetings or at the exhibitors' own works. The problems of the industry are so variable that standard apparatus has frequently to be modified to meet the particular requirements, and the Germans are known to be particularly adaptable in this respect.

The exhibits covered a wide field and were perhaps the more valuable in consequence, whereas the last exhibition of British chemical plant held in London, at the time of the jubilee of the Society of Chemical Industry, was restricted almost entirely to plant. Such collective displays as those made by the publishers of the many technical and scientific books were a feature that should be copied, as also the exhibit covering safety regulations and precautions in the industry. It is proper that chemists should be as meticulous in the treatment of the health and safety of their work people as they are of their reactions, and indeed it is well known that the industry is one of the safest in spite of the potentialities for danger in it.

The tendency, if there were one, was towards the exhibit of apparatus for copying large-scale working in the laboratory. The development of chemical processes at high pressures and elevated temperatures had its influence on the apparatus exhibited, whilst the ceramic section, which was a particularly good one, illustrated the progress which has been made in using substances which corrode metals or require high temperatures to react.

As compared with the last exhibition, there was less display of large-scale processes requiring a good cieal of space and plant for the exhibit, more attention being paid to details. The urge to break away from tradition was sometimes in evidence as, for example, in the vest-pocket microscopes.

The spacious gangways made it physically possible to spend some hours at a time at the somewhat arduous task of examination, and the important social side was facilitated by a club room for overseas visitors and other concomitants associated with the Rhine.

Dr. Bretschneider, the organiser of the exhibition, was in evidence on all occasions as a willing and charming helper to all visitors, and all felt how much they owed to his indefatigable energy in organising such a treasure house of chemical weapons. The British visitors found the Rhineland and the Moselle as simple, clean and convivial as ever, whilst travelling was in no way fettered by restrictions of currency or otherwise-they received a real welcome from all. It is well to record that at no time did they see any evidence which would lead them to believe that other than a peaceful reconstruction of Germany is taking place.

\section{Annual Conference of the Association of Teachers in Technical Institutions}

$A^{T}$ the recent (twenty-fifth) annual Conference of the Association of Teachers in Technical Institutions, held at Middlesbrough, Mr. H. J. Cull, of the Central Technical College, Birmingham, took over the presidency of the Association from Mr. F. H. Reid, of the Technical Institute, Paddington.

Mr. Cull opened his presidential address with a survey of the results of the application of science to industrial processes, and stressed specially the growth of 'technological unemployment'. "These are the days," he said, "of the second industrial revolutionthe coming into full use of electricity and the internal combustion engine. The difficulties are greater than those which marked the passage into full use of steam power, mainly on account of the speed of the development." He instanced the following as illustrations of his point : the rise in production of several nations between 1925 and 1929 was 38 per cent in Poland, 54 per cent in Canada, 30 per cent in France, 22 per cent in Germany, 14 per cent in the United States and 13 per cent in Great Britain. More important, perhaps, was the physical output per worker: in Great Britain in 1924-29 there was an increase of 11 per cent. The figure for the United States rose by 50 per cent in a quarter of a century. In 35 typical American factories the output per man-hour between 1919 and 1927 rose 74 per cent. "It is futile," said Mr. Cull, "to think of retarding these scientific applications, and of 'scientific holidays', and so the consequences remain to be faced ... it is now apparent that this machine age will demand that, if employment is to be continuous, skill will be judged by adaptability. It is for future consideration to show the precise form of the demands of this changing industrial condition on the technical teacher." Mr. Cull then linked with his general picture of these industrial changes their implications of the work of junior technical schools, juvenile instruction centres, continuation classes, regional co-ordination of technical education, etc., and the need for educational research. $\mathrm{He}$ also directed special attention to the course for laboratory assistants promoted by the 
Institute of Physies in order to remove from some of these appointments the suggestion of blind-alley employment.

At the Association's annual dinner, the question of industrial changes and the need for adaptability was deftly sketched by Dr. R. E. Slade (Imperial Chemical Industries, Ltd.) who responded to the toast of "Education and Industry". Since world markets are changing, he said, industry must keep pace with the changes. On the north-east coast, industry has one of the finest positions in a free-trade world, but since the free-trade world no longer exists, industry is compelled to adjust itself. At the Imperial Chemical Industries works at Billingham they set out to send nitrogenous fertilisers all over the world. The plant was completed in 1929. But the world now requires only a portion of these fertilisers, and the firm had to turn its attention to other products for home and export purposes. The factory is now working hard on other things, and is being extended. Dr. Slade insisted that changes in industry can be achieved only by full confidence in technical and research staffs. Only the association of commercial minds with scientific and technical possibilities will lead to success. Workers on Tees-side, he declared, are wonderfully adaptable, and this is due to technical training.

A resolution passed during the Conference urged the necessity of grace periods up to one year in order that technical teachers could undertake research or gain further industrial experience. Other resolutions pressed for an extension of part-time day classes which would be attended by students during the normal working hours of industry, and for closer co-operation between the Board of Education and the Ministry of Labour in connexion with juvenile instruction centres.

\section{University and Educational Intelligence}

Cambridge.-Dr. O. M. B. Bulman, of Sidney Sussex College, has been appointed University lecturer in geology. M. Black, of Trinity College, has been appointed University demonstrator in geology, Dr. G. N. Myers, of Sidney Sussex College, University demonstrator in pharmacology and Dr. H. A. Krebs University demonstrator in biochemistry.

An election to the Isaac Newton studentships will be held early in the Michaelmas Term 1934. These studentships are for the furtherance of advanced study and research in astronomy (especially gravitational astronomy) and physical optics. Candidates are invited to send in their applications to the ViceChancellor between October 9 and October 15 .

Liverpool--Dr. Henry Cohen, lecturer in medicine in the Cniversity and honorary physician to Liverpool Royal Infirmary, has been appointed to the chair of medicine in the University in succession to Prof. John Hay, who retires at the end of the present session.

Prof. L. M. Milne-Thomson, assistant professor of mathematics at the Royal Naval College, Greenwich, has been appointed professor as from September 30 next.

AN International University Conference has been arranged by the Association of University Teachers to be held at Oxford on June 29-July 2. This Conference will be the first attempt to form an organ of direct co-operation between universities of all countries. Among the subjects to be discussed at the Conference are: university organisation, vocational instruction, interchange of teachers, opportunities for research by foreign students, academic freedom. Further information can be obtained from Prof. R. C. McLean, University College, Cardiff.

THE first Register of the London School of Economies and Political Science (Houghton Street, Aldwych. 3s. 6d.) which has just been published contains, in addition to short biographies of former students and a list of lecturers since 1895, an interesting introduction contributed by Sir William Beveridge, the director of the School, describing its growth. At first the School did not prepare students specifically for examinations. In 1895 there was no teaching University of London, no internal degree, no university professoriate and no faculty of economics. There was an examination authority and there were individual colleges such as University, King's or Bedford, but these had no organic relation to each other or to the examining authority. The teaching University as it has grown since 1900 out of the London colleges is a new thing altogether. Since the War, there has been a rapid growth in the number of regular students of normal university type attending the School, and this has been accompanied by a decline in those listed as occasional. The number of regular students is now about 1,300 , that of occasional students about 1,100, while the regular teaching staff numbers 89 .

THE report of the president of Columbia University, New York, Dr. Nicholas Murray Butler, for 1933 includes a discussion of some fundamental questions relating to the organisation and development of universities in the United States. Dr. Butler admits the confusion which results from the lack of an official definition of a university in the United States and of authority for its creation and recognition. "Nothing is easier than for a college in this country to call itself a university, even though it has not the first characteristic of university organisation, method or ideal". There is no such thing as a private university, he says. Some may be supported by taxes and others not, but all are public institutions. The American college covers the field which on the Continent is occupied by the upper years of the lycée or gymnasium and the first year of the university. Hence there are but 11 universities in England, 4 in Scotland, 1 in Wales, 5 in Belgium and 8 in Holland, 17 in France and 23 in Germany, 3 in Austria, 4 in Hungary, 25 in Italy and 11 in Spain. But in the United States there are 263 universities, colleges and technological institutions approved by the Association of American Universities. Of these, 36 are institutions having a more or less complete university organisation. The World Almanac lists 579 universities and colleges in the United States. The tendency in the United States appears to be to regard the graduate student only as doing 'university' work. "The university student", says Dr. Butler, "has a quite different outlook and a quite different method of approach to his field of intellectual interest." The teaching staff at Columbia in 1932-33 was 3,064 (comparing with 3,255 for the previous session) and 5,609 degrees, certificates and diplomas were granted, the total number of resident students being 30,588 , of whom 13,144 were graduate and professional students. 